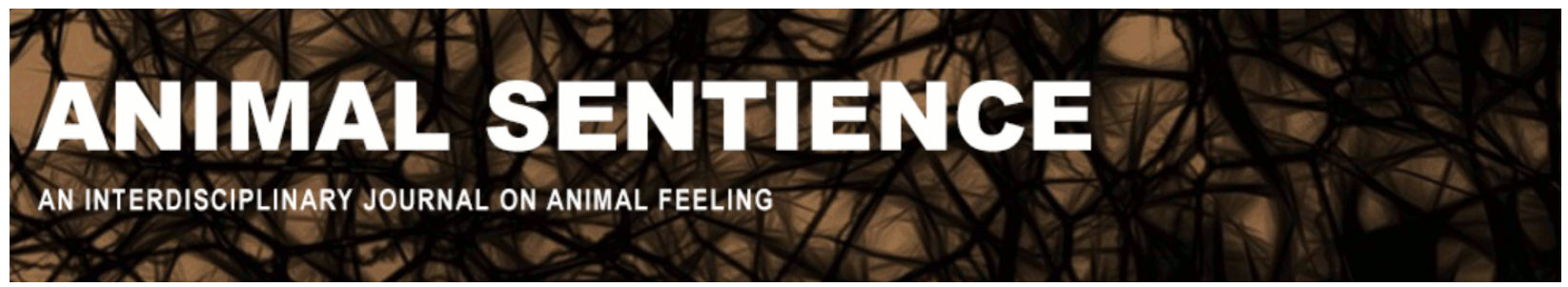

Anomaly, Jonathan (2020) Cultured meat could prevent the next pandemic. Animal Sentience 30(5)

DOI: $10.51291 / 2377-7478.1633$

Date of submission: $2020-08-23$

Date of acceptance: 2020-08-23

(c)

This article has appeared in the journal Animal

Sentience, a peer-reviewed journal on animal

cognition and feeling. It has been made open access,

free for all, by WellBeing International and deposited

in the WBI Studies Repository. For more information,

please contact

wbisr-info@wellbeingintl.org.

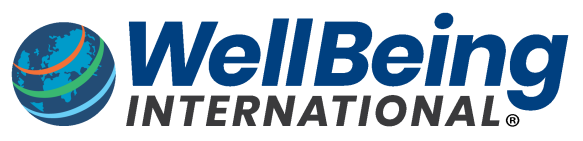

SOLUTIONS FOR PEOPLE, ANIMALS AND ENVIRONMENT 


\title{
Cultured meat could prevent the next pandemic
}

Commentary on Wiebers \& Feigin on Covid Crisis

\author{
Jonathan Anomaly \\ Philosophy, Politics, \& Economics Program, University of Pennsylvania
}

\begin{abstract}
Wiebers \& Feigin identify intensive agriculture and trade in exotic animals as the main sources of novel zoonotic viral infections. They recommend a transition away from meat. I would add that we would do well to invest in the mass production of cultured meat, derived from stem cells, as a radical alternative to animal agriculture.
\end{abstract}

Jonathan Anomaly directs the philosophy, politics, and economics (PPE) program at the University of Pennsylvania. His academic interests include ethical issues surrounding animal agriculture, antibiotic resistance, and genetic engineering. Website

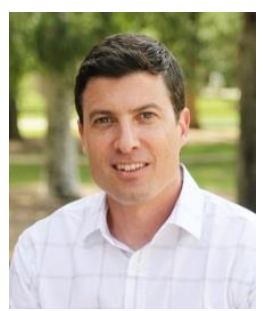

In their incisive target article on the origin of the current pandemic, Wiebers \& Feigin (2020) (W\&F) raise an important issue that most journalists ignore: the role of animal agriculture and the consumption of exotic animals in creating novel infectious diseases in humans. By turning the pandemic into a political football, journalists and other leaders have done the public a disservice. They have failed to explain how zoonotic infections work; they have also failed to scrutinize the Chinese government's role in covering up the origins of a pandemic that emerged in Wuhan.

Antibiotics. W\&F provide a useful overview of how the problem of antibiotic resistance in people is exacerbated by the use of antibiotics in agriculture (Anomaly 2019). In particular, intensive animal farming is increasing around the world, from China to Egypt, at precisely the time when Europe and the United States have started to crack down on the use of antibiotics in animal farming. Moreover, W\&F note, many of the deadliest strains of influenza over the last century can be traced to farm animals, whether or not they're raised intensively.

Environmental Footprint. The solution W\&F propose is "additional investment in plant-based agriculture to grow crops to feed humans rather than livestock for human consumption." As W\&F point out, more plant-based protein "will feed more people while utilizing far less land and water, allowing for the preservation of vital ecosystems for innumerable species." It is undoubtedly true that developing countries - which have the highest population growth may need to consume less meat and more vegetable proteins. But rich countries also have reason to invest more in developing cultured meat, created from animal stem cells in laboratories. If the price of cultured (or "clean") meat could be brought down to affordable levels, it would not only reduce the environmental footprint of animal agriculture, it would also please customers, reduce animal suffering, and dramatically decrease the risk of zoonotic diseases from agriculture.

Sentience and Interests. Near the end of their article, W\&F say that "the time has come for us to rethink our relationship with all life on this planet - other humans, nonhumans, and the 
earth, a life form in itself. What is good for nonhumans and the earth is virtually always in the best interests of humans, given the profound interconnectedness of all life." I think we can be responsible stewards of nature while rejecting the idea that the earth has interests. The earth is not a form of life; it does not have interests in the way sentient creatures do.

Pointless Pain. Ecosystems also lack interests. What makes ecosystems worth saving is the intrinsic value of their beauty and complexity, and the instrumental value of the services they perform for us. Natural spaces, including ecosystems, are a necessary condition for human life to function, and to flourish. But we don't owe anything to the earth, or to ecosystems. Instead, we owe it to future people to preserve ecosystems and to make the earth a place worth living (Treves et al. 2019). This means treating animals with respect, preserving endangered species and ecosystems, and taking precautionary measures to prevent the emergence of zoonotic infectious diseases. We can do this by pressuring governments around the globe to ban the trade in exotic animals, eliminate wet markets, increase roaming space for farmed animals, and invest in the creation and mass production of cultured meat. While meat derived from stem cells may seem creepy to some people, it's vastly preferable to the pointless pain that animals on factory farms currently endure, and the preventable diseases they spread to human beings. ${ }^{1}$

\section{References}

Anomaly, J. (2019) Intensive Animal Agriculture and Human Health. In: Fischer, B. (Ed.) Routledge Handbook of Animal Ethics. Routledge.

Treves, Adrian; Santiago-Ávila, Francisco J.; and Lynn, William S. (2019) Just preservation. Animal Sentience 27(1).

Wiebers, David and Feigin, Valery (2020) What the COVID-19 crisis is telling humanity. Animal Sentience 30(1)

\footnotetext{
${ }^{1}$ Editor's note: Title changed in July 2021 -- from "would" to "could" and "COVID-19 crisis" to "pandemic" - to reflect continuing uncertainty about the laboratory-origins hypothesis for the origin of the COVID-19 mutation.
} 